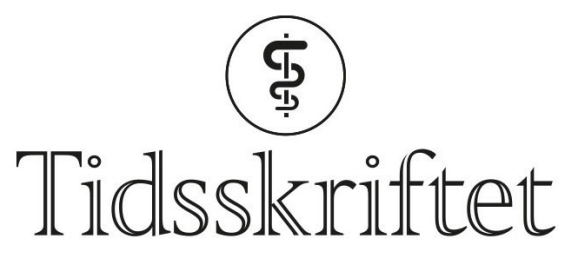

DEN NORSKE LEGEFORENING

\title{
Datoformater i Tidsskriftet
}

SPRÅKSPALTEN

\section{EIRIK MADSEN}

E-post: eirik.madsen@helse-forde.no

Eirik Madsen (f. 1987) er lege i spesialisering ved Førde sentralsjukehus.

Tidsskriftet anbefaler at dato og årstall skal skrives med mellomrom mellom måneden og årstallet. Det er feil.

Ifølge Språkrådet skal datoer i løpende tekst skrives med rekkefølgen dag-måned-år (1). Det finnes flere likeverdige skrivemåter å velge mellom, og bruken varierer mellom ulike medier og tekstsjangre.

I litteraturlister i Tidsskriftet brukes konsekvent den godkjente formen D(D).M(M).ÅÅÅÅ (f.eks.14.8.2017), men for øvrig bruker Tidsskriftet en annen variant av ovennevnte datoformat. Her brukes et mellomrom mellom måneden og årstallet: D(D).M(M). ÅÅÅÅ (f.eks. 14.8. 2017). Sistnevnte datoformat er ikke godkjent av Språkrådet, men er likevel anbefalt skrivemåte, ifølge Tidsskriftets forfatterveiledning (2).

Det fremstår litt underlig at Tidsskriftet anbefaler og har valgt å ta i bruk et datoformat som ikke er i tråd med gjeldende norsk rettskrivning. Har Tidsskriftet en kommentar til valg av nevnte datoformater?

Les Erlend Hems svar.

\section{LITTERATUR:}

1. Dato. I: Tall, tid og dato. Språkrådet. www.sprakradet.no/sprakhjelp/Skriveregler/Dato/\#dato (2.5.2017).

2. Talluttrykk. Forfatterveiledning. Tidsskrift for Den norske legeforening. http://tidsskriftet.no/annet/talluttrykk (2.5.2017).

Publisert: 2. oktober 2017. Tidsskr Nor Legeforen. DOI: 10.4045/tidsskr.16.1121 (C) Tidsskrift for Den norske legeforening 2020. Lastet ned fra tidsskriftet.no 